\title{
ARTHROPOD PREDATORS IN CABBAGE (CRUCIFERAE) AND THEIR POTENTIAL AS NATURALLY OCCURRING BIOLOGICAL CONTROL AGENTS FOR PIERIS RAPAE (LEPIDOPTERA: PIERIDAE)
}

\author{
Mark A Schmaedick ${ }^{1}$ and Anthony M Shelton \\ Department of Entomology, New York State Agricultural Experiment Station, Cornell \\ University, Geneva, New York, United States 14456
}

\begin{abstract}
The Canadian Entomologist 132: 655 - 675 (2000)

We used three sampling methods to identify the arthropod predators most abundant and active in fields of cabbage, Brassica oleracea L. var. capitata, and determined those most likely to be important predators of the imported cabbageworm, Pieris rapae L., by testing the predators' abilities to forage on cabbage plants and to feed on Pieris rapae in small arenas in the laboratory. Abundance and activity in the field were monitored with pitfall traps, sticky traps applied directly to leaves, and plant samples. Four criteria were used to assess the species' potential value as a predator of Pieris rapae in cabbage: relatively high overall abundance in trap catches and plant samples, occurrence on plant foliage in the field, a high propensity to feed on Pieris rapae eggs and first instars, and the ability to search for larval Pieris rapae on cabbage plants. Four species, the wolf spider Pardosa milvina (Hentz) (Araneae: Lycosidae), the harvestman Phalangium opilio L. (Opiliones: Phalangiidae), and the lady beetles Coleomegilla maculata lengi Timberlake and Hippodamia variegata (Goeze) (Coleoptera: Coccinellidae), demonstrated these attributes, although all four species appeared unable to search for prey on some parts of the cabbage plants, owing to unsure footing on the plants' slippery cuticular wax. Linyphiids (Araneae) and syrphids (Diptera), the most abundant taxa in the plant samples, may prove better at thoroughly searching cabbage plants, but remain to be tested in future laboratory trials. Our results show that only a small portion of the predatory arthropod species that occur in cabbage fields is likely to prey on Pieris rapae on the plants, although important questions remain about the roles of some taxa. Future efforts to enhance biological control of Pieris rapae by naturally occurring predators can now focus on further elucidating and finding ways to enhance the roles of those predators that are effective.
\end{abstract}

Schmaedick MA, Shelton AM. 2000. Prédateurs arthropodes naturellement présents dans les champs de choux et leurs efficacités potentielles dans la lutte biologique contre Pieris rapae (Lepidoptera : Pieridae). The Canadian Entomologist 132 : 655-675.

\section{Résumé}

Nous avons identifié les prédateurs arthropodes les plus abondants et actifs sur le choux, Brassica oleracea L. var. capitata, en utilisant trois méthodes de recensement en champ. Ensuite nous avons identifié les espèces de ces arthropodes les plus susceptibles d'être des prédateurs efficaces de la piéride du chou, Pieris rapae L., en utilisant un examen en laboratoire de leurs aptitudes à rechercher des proies sur plantes entières et à consommer des piérides du chou (oeufs ou larves). Nous avons recensé l'abondance et l'activité de ces prédateurs potentiels au moyen de pièges à fosses, de pièges gluants déposés sur feuilles et d'échantillonages de plantes. Nous avons utilisé quatre critères pour évaluer le potentiel de chaque espèce étudiée: son abondance relative dans les pièges et sur plantes, l'efficacité de sa recherche de proies sur plantes, et sa consommation d'oeufs et de larves de Pieris rapae. Quatre espèces se sont avérées intéressantes : la lycose Pardosa milvina (Hentz) (Araneae :

\footnotetext{
${ }^{1}$ Author to whom all correspondence should be sent at the following address: Land Grant Program, American Samoa Community College, Box 5319, Pago Pago, American Samoa, United States 96799.
} 
Lycosidae), l'opilion Phalangium opilio L. (Opiliones : Phalangiidae), et les coccinelles Coleomegilla maculata lengi Timberlake et Hippodamia variegata (Goeze) (Coleoptera : Coccinellidae). Cependant, chacune de ces espèces est incapable de consommer des piérides sur certaines parties de la plante en raison de la présence de cires épicuticulaires qui gênent leurs déplacements. Il est possible que les linyphiidés (Araneae) et les syrphides (Diptera), les prédateurs les plus abondants dans nos échantillons de plantes entières, ne sont pas gênés par ces cires. Néanmoins, leurs aptitudes à rechercher des proies sur plantes entières reste à être évaluée. Nos résultats montrent que seule une petite proportion des prédateurs présents aux champs ont le potentiel d'être des prédateurs efficaces de Pieris rapae. Le rôle de ces prédateurs pourrait être accentué dans un programme de lutte biologique contre Pieris rapae basé sur l'utilisation de prédateurs naturellement présents dans les champs de choux.

\section{Introduction}

As one of the most common butterflies and a serious pest of crucifer crops in many parts of the world, Pieris rapae L. (Lepidoptera: Pieridae) has received a great deal of attention from lepidopterists and agricultural entomologists (Gilbert and Singer 1975; Jones 1981; Ehrlich 1984; Courtney 1986; Lokkers and Jones 1999). Despite its importance, little is known about the impact of predatory arthropods on Pieris rapae populations, although several studies suggest it may be substantial (Dempster 1967, 1984; Parker 1970; Ashby 1974; Hasui 1977; Jones et al. 1987). Earlier reports have documented high levels of mortality from arthropod predators (Schmaedick and Shelton 1999) and reported on extensive pitfall-trapping of ground-dwelling predators (Shelton et al. 1983a) in fields of cabbage, Brassica oleracea L. var. capitata (Cruciferae), in central New York State. In the current study, we used pitfall-trapping, along with other sampling methods and laboratory predation assays, to monitor arthropod predators in cabbage fields and assess their potential as naturally occurring biological control agents for Pieris rapae.

Immature Pieris rapae are reported to rarely leave suitable host plants before they disperse for pupation (Harcourt 1961; Jones 1977). This habit would likely reduce the opportunity for predation on early stage Pieris rapae by the surface-active predators typically captured by pitfall-trapping. Nevertheless, pitfall-trapping, combined with other sampling techniques, remains an important tool for assessing the potential impact of predators on foliar-dwelling herbivores for several reasons. First, many predators spend time both on plants and on the soil surface, and pitfall traps may be the most effective way to monitor some of these predators. Second, studies in other crops have shown that soil surface dwelling predators may have a significant impact on populations of foliar-dwelling herbivores when the presence of other predators on the foliage causes the herbivores to move off or be dislodged from the plants (Dennis and Sotherton 1994; Losey and Denno 1998a, 1998b). Third, a great deal of information has recently become available on predator-predator and predator-detritivore interactions and their effects on biological control in agricultural systems (e.g., Polis and Myers 1989; Rosenheim et al. 1995; Settle et al. 1996; Fagan et al. 1996; Rosenheim 1998; Snyder and Wise 1999). As a result, agricultural entomologists now recognize that they cannot hope to understand individual predator-prey relationships in isolation from the larger food webs of which they are a part. We therefore approached the problem of determining which predator species may be affecting Pieris rapae populations by first using several sampling techniques, including pitfall traps, sticky traps, and above-ground plant samples, to determine the relative abundance and activity of arthropod predators in cabbage fields. We then focused on those species most likely to affect the early stages of 
Pieris rapae directly, owing to their occurrence on plants in the field, and tested their abilities to forage on cabbage plants and feed on Pieris rapae in the laboratory.

\section{Materials and Methods}

Field Study Sites. Trapping with pitfall traps and sticky traps was conducted at three sites in 1995 and two sites in 1996. Plant samples were taken from the two 1996 sites. The sites were 0.2 ha square plots of 'Vantage Point' transplanted 6-10 June 1995 and 'Cheers' transplanted 22-26 May 1996. The plots were located at the Fruit and Vegetable Research Farm of the New York State Agricultural Experiment Station at Geneva, New York $\left(42^{\circ} 53^{\prime} \mathrm{N}, 77^{\circ} 02^{\prime} \mathrm{W}\right)$ and were separated by $>500 \mathrm{~m}$ in 1995 and by $160 \mathrm{~m}$ in 1996. Soil at the research farm is mostly Lima silt loam (fine-loamy, mixed, mesic, Glossoboric Hapludalf) (US Department of Agriculture 1958). Precipitation averages $65 \mathrm{~cm}$ annually, and temperatures range from a January mean daily low of $-9^{\circ} \mathrm{C}$ to a July mean daily high of $28^{\circ} \mathrm{C}$ (Vittum et al. 1983). Standard agronomic practices were followed in all the fields and no fungicides or insecticides were applied. The plots were bordered by a 3- to 5-m strip in which weeds were controlled by disking and rototilling, and all trapping and sampling took place $>3 \mathrm{~m}$ from the edge of the planted areas. Surrounding areas consisted of deciduous woodlands, fallowed fields of grasses and forbs, gravel roadways, and fields planted to corn, Zea mays L. (Poaceae); tomatoes, Lycopersicon esculentum Miller (Solanaceae); cabbage; squash, Cucurbita L. spp. (Cucurbitaceae); alfalfa, Medicago sativa L. (Fabaceae); and sorghum-sudan grass, Sorghum bicolor L. $\times$ Sorghum sudanense Bailey (Poaceae).

Pitfall Traps. Dry pitfall traps, consisting of two 296-mL clear plastic cups $(7.2 \mathrm{~cm}$ diameter opening; Solo Cup Co., Urbana, Illinois) placed one inside the other, were embedded in the soil, replacing every 13th plant in every sixth row in a $7 \times 7$ grid in the plot center. Each trap was protected from rain and direct sunlight by an inverted 15.2-cm-diameter white plastic disposable plate (Solo Cup Co.) held approximately $3 \mathrm{~cm}$ above the trap by a binder clip fastened to a 14-gauge wire inserted into the soil beside the trap. Squat $266-\mathrm{mL}$ plastic cups ( $9 \mathrm{~cm}$ diameter opening; Solo Cup Co.) were inserted into the mouth of each trap to close it and were held in place by the inverted plate cover. The traps were opened for a $24-\mathrm{h}$ period weekly, during which they were emptied twice, at approximately 08:00 and 20:00, before closing them until the following week. Captured arthropods were immediately placed in containers embedded in ice and were later frozen at -20 or $-80^{\circ} \mathrm{C}$ (according to space available in freezers) until they could be examined. Trapping was conducted for 7 weeks (from 28 June to $9 \mathrm{Au}$ gust) in 1995 and 11 weeks (from 19 June to 28 August) in 1996. Predatory arthropods were identified to the lowest taxonomic level possible and the abundance of the most common species was determined for each plot and sampling time.

Sticky Traps. Sticky traps were placed on 36 plants, approximately every 13 th plant in every sixth row, forming a $6 \times 6$ grid in the center of each plot. The traps consisted of two 8.6-cm rings of insect trap coating (Tanglefoot Co., Grand Rapids, Michigan) applied to each plant, one on the upper surface of a frame leaf and another on the lower surface of a frame leaf roughly opposite the first. On the first trapping date in 1996, when the leaves were small, the traps consisted of $5-\mathrm{cm}$-diameter circles instead of the larger rings. In 1995, the trapping began on 10 July and continued until 14 August. Predatory arthropods were collected from the traps every 3-4 d, and every week the coated leaves were removed and new trap coating applied to leaves of the same or nearby plants. In 1996, trapping was done for one 24-h period each week from 19 June 
until 28 August, and traps were checked at approximately 08:00 and 20:00 during each trapping period, after which the coated leaves were removed from the fields. Trapped predatory arthropods were placed in petri dishes on ice for transport to the laboratory, where they were stored at $-80^{\circ} \mathrm{C}$ until they could be cleaned and examined. All were identified to the lowest taxonomic level possible, and numbers of the most abundant species were determined for each plot and sampling time.

It has been shown that some natural enemies are attracted to plants that are damaged by their herbivore prey (Whitman and Nordlund 1994). It is possible that removing the leaves bearing sticky traps after each trapping period could have increased plant damage over background levels enough to increase the attractiveness of the plants to certain arthropod predators, thus increasing trap catches. We did not investigate this possibility further. Such a bias, if it existed, represents one of many potential biases associated with this or any trapping method.

Plant Sampling. On 20 June, 4 July, 18 July, and 7 August 1996, plant samples were taken from the two study plots. At eight sampling times on each of the four sampling dates, 30 randomly selected plants per plot were sampled by quickly placing a large plastic bag over the plant, closing it around the plant base, cutting the stem at ground level, and then tying the bag closed. The samples were taken at 02:00, 05:00, 08:00, 11:00,14:00, 17:00, 20:00, and 23:00 and were held at $2^{\circ} \mathrm{C}$ until they could be examined leaf by leaf in the laboratory. (Median time between sampling and examination of the plants was $6 \mathrm{~d}$.) Samples were taken at all times of the day, to ensure that any predators that tend to move on and off plants in a daily cycle would not be missed. All predatory arthropods were removed from the plants and stored at $-80^{\circ} \mathrm{C}$ until they could be examined further. (Some predator pupae were not frozen but, instead, were reared to adults for identification.) Over the season, a total of 1920 plants was examined ( 2 plots $\times$ 8 sampling times $\times 4$ sampling dates $\times 30$ samples). Predators were identified to the lowest taxonomic level possible and the abundance of the most numerous predators was displayed graphically by plot and sampling date. Voucher specimens from the pitfalltrapping, sticky-trapping, and plant-sampling were placed in the Cornell University Insect Collection under lot number 1239.

Predation in Small Arenas. Selected species that were found to occur in the study plots were collected from cabbage fields and surrounding areas and tested for their ability to prey on Pieris rapae eggs and first instars in small arenas in the laboratory. Species were selected on the basis of their relative abundance in the trap captures and plant samples and our ability to positively identify and collect enough individuals to test. In addition, nabids and anthocorids (Insecta) were also included in this and the following experiment, despite their rarity or absence in the trapping and plant-sampling. We included these predators in the experiments, because these groups were found to be relatively abundant in cabbage by Oatman and Platner (1969) and Weires and Chiang (1973) and in preliminary sampling done by us (MA Schmaedick, unpublished data). The predators were placed individually in 473-mL white plastic "deli" containers with clear tops (Fabri-Kal Corp.) lined with filter paper and provided with a moist $2.5-\mathrm{cm}$ length of cotton dental wick. The arenas containing the predators were placed in an environmental chamber at $15 \mathrm{~L}\left(22^{\circ} \mathrm{C}\right): 9 \mathrm{D}\left(17^{\circ} \mathrm{C}\right)$ and $60 \% \mathrm{RH}$, and starved for $24 \mathrm{~h}$ before adding either 10 or 20 Pieris rapae eggs or five first instars. These environmental conditions were chosen to approximate those occurring in central New York State during the cabbage-growing season. Eggs and first instars were used in the tests, because earlier work indicated that almost all mortality from arthropod predators occurred during these stages (Schmaedick and Shelton 1999). The eggs were presented on pieces cut from parafilm sheets used for oviposition in a laboratory colony of Pieris rapae 
(Webb and Shelton 1988). The first instars were transferred shortly after hatching to 3.2-cm cabbage leaf disks that were then placed with the predators. After an additional $24 \mathrm{~h}$, the remaining eggs or larvae were counted. At least 19 test arenas containing individual predators were used for each species - Pieris rapae stage combination. A minimum of five control arenas, identical to the test arenas except without predators, were included with each batch of predators tested. No eggs or larvae were damaged or disappeared in any of the control arenas.

Predation on Cabbage Plants in the Laboratory. A subset of the predator species that had been found to occur in cabbage plots and which fed on Pieris rapae in the small-arena assays was tested for the ability to prey on first-instar Pieris rapae on potted cabbage plants in cages in the laboratory. Predators were collected from cabbage fields and surrounding areas and starved for $24 \mathrm{~h}$, as for the small-arena experiments. Groups of predators were then placed in clear-plastic cylinder cages with screen tops covering small (4- to 6-leaf) cabbage plants. The cabbage plants had been transplanted into $25 \mathrm{~cm}$ diameter pots containing a moist mason sand substrate (BR DeWitt, Inc., Phelps, New York) and infested with 10 first instar Pieris rapae $24 \mathrm{~h}$ earlier. The cylinder cages fit tightly inside the pot rims at the level of the substrate and were coated with a thin layer of fluon (Northern Products, Woonsocket, Rhode Island), which prevented the predators from climbing the sides and kept them confined to the substrate and plant. A moist $2.5-\mathrm{cm}$ length of cotton dental wick was placed on the substrate surface in each pot. After $24 \mathrm{~h}$ at $22^{\circ} \mathrm{C}, 40 \% \mathrm{RH}$, and $16 \mathrm{~L}: 8 \mathrm{D}$, the remaining larval Pieris rapae were counted. Three control plants, with Pieris rapae but no predators, were included in each trial. No larvae disappeared from any of the control plants.

\section{Results}

Pitfall Traps. The Carabidae (Insecta), Staphylinidae (Insecta), and Linyphiidae (Arachnida) comprised most of the species caught in the pitfall traps. (Table 1 presents taxonomic authorities, order, and family for all genera and species.) With a few exceptions, the most numerous taxa in the traps also belonged to these families (Fig. 1). Only five species were captured in numbers that comprised $5 \%$ or more of the total catch of arthropod predators in the pitfall traps: Phalangium opilio (Arachnida; 15\%), Bembidion quadrimaculatum oppositum (Insecta; 14\%), Elaphropus anceps (Insecta; 7\%), Stenolophus comma (Insecta; 6\%), and Pterostichus melanarius (Insecta; 5\%). Two additional taxa that were not identified to species level also comprised $>5 \%$ of total captures: centipedes (Chilopoda) [Lithobiidae (sensu lato)] (7\%) and the Athetini (Insecta; 6\%). Lithobiidae, among the most abundant predators in 1995, were relatively scarce in 1996 (Fig. 1). Tinotus sp. (Insecta), although relatively abundant overall, occurred almost solely in plot 1 (Fig. 1). Lasius sp. (Insecta) were also restricted in their occurrence, with $44 \%$ of the 2-year total being trapped on the final sample date in plot 3. Traps in plot 1 in 1995 had unusually high numbers of Bembidion quadrimaculatum and Phalangium opilio (Fig. 1). Plot 1 was by far the weediest of the five plots, Weed levels in midseason probably exceeded what would be tolerated by most commercial growers. It was also unique in being located in an area surrounded by weedy fallow land, whereas the other four plots were surrounded by unpaved access roads and cultivated areas.

Seasonal patterns were evident for some species but not for others (Figs. 2 and 3). Immature Phalangium opilio tended to be more abundant late in the season, while adults were more abundant early in the season (Fig. 2A). Pardosa sp. (Arachnida) numbers peaked in midseason in both years (Fig. 2B). The large numbers of Tennesseellum 
TABLE 1. Predatory arthropods captured in cabbage fields in pitfall traps (PF), sticky traps (ST), and plant samples (PL).

\begin{tabular}{|c|c|c|c|c|c|}
\hline & Order & Family & $\mathrm{PF}$ & ST & PL \\
\hline \multicolumn{6}{|l|}{ Arachnida } \\
\hline Achaearanea tepidariorum (C.L. Koch) & Araneae & Theridiidae & & & $x$ \\
\hline Anyphaenidae (immature, no further identification) & Araneae & Anyphaenidae & & . & $\times$ \\
\hline Araniella displicata (Hentz) & Araneae & Araneidae & & & $x$ \\
\hline Catabrithorax plumosus (Emerton) & Araneae & Linyphiidae & $x$ & & \\
\hline Clubiona Latreille sp. & Araneae & Clubionidae & & $x$ & $x$ \\
\hline Clubiona pygmaea Banks & Araneae & Clubionidae & & $x$ & \\
\hline Coriarachne versicolor Keyserling & Araneae & Thomisidae & & & $x$ \\
\hline Dictyna bostoniensis Emerton & Araneae & Dictynidae & & & $x$ \\
\hline Dictyna foliacea (Hentz) & Araneae & Dictynidae & & & $x$ \\
\hline Diplostyla concolor (Wider) & Araneae & Linyphiidae & $x$ & & \\
\hline Drassyllus depressus (Emerton) & Araneac & Gnaphosidae & $x$ & & \\
\hline Eperigone Crosby and Bishop sp. & Araneae & Linyphiidae & $x$ & & \\
\hline Eperigone tridentata (Emerton) & Araneae & Linyphiidae & $x$ & & \\
\hline Eperigone trilobata (Emerton) & Araneae & Linyphiidae & $x$ & & \\
\hline Erigone atra Blackwall & Araneae & Linyphiidae & $x$ & & \\
\hline Erigone Audouin sp. & Araneae & Linyphiidae & $x$ & & $x$ \\
\hline Erigone autumnalis Emerton & Araneae & Linyphiidae & $x$ & & \\
\hline Grammonota inornata Emerton & Araneae & Linyphiidae & $x$ & & \\
\hline Hadrobunus maculosus (Wood) & Opiliones & Phalangiidae & $x$ & & \\
\hline Islandiana Braendegaard sp. & Araneae & Linyphiidae & $x$ & & \\
\hline Islandiana flaveola (Banks) & Araneae & Linyphiidae & $x$ & & $x$ \\
\hline Islandiana longisetosa (Emerton) & Araneae & Linyphiidae & $x$ & & $x$ \\
\hline Leiobunum bracchiolum McGhee & Opiliones & Phalangiidae & $x$ & & \\
\hline Linyphia pusilla Sundevall & Araneae & Linyphiidae & $x$ & & $x$ \\
\hline Meioneta unimaculata (Banks) & Araneae & Linyphiidae & $x$ & $x$ & $x$ \\
\hline Metaphidippus Cambridge sp. & Araneae & Salticidae & & $x$ & \\
\hline Neoantistea Gertsch sp. & Araneae & Hahniidae & & & $x$ \\
\hline Ozyptila praticola (C.L. Koch) & Araneae & Thomisidae & $x$ & & \\
\hline Pardosa milvina (Hentz) & Araneae & Lycosidae & $x$ & $x$ & \\
\hline Pardosa saxatilis (Hentz) & Araneae & Lycosidae & $x$ & & \\
\hline Phalangium opilio L. & Opiliones & Phalangiidae & $x$ & $x$ & $x$ \\
\hline Philodromus rufus Walckenaer & Araneae & Philodromidae & & & $x$ \\
\hline Pirata minutus Emerton & Araneae & Lycosidae & $x$ & & \\
\hline Salticidae (immature, no further identification) & Araneae & Salticidae & & & $x$ \\
\hline Steatoda americana (Emerton) & Araneae & Theridiidae & $\times$ & & \\
\hline Tennesseellum formicum (Emerton) & Araneae & Linyphiidae & $x$ & & $\times$ \\
\hline Tetragnatha laboriosa Hentz & Araneae & Tetragnathidae & & $x$ & $x$ \\
\hline Tetragnatha versicolor Walckenaer & Araneae & Tetragnathidae & & & $x$ \\
\hline Theridion bimaculatum (L.) & Araneae & Theridiidae & & & $x$ \\
\hline Theridula emertoni Levi & Araneae & Theridiidae & & & $x$ \\
\hline Tibellus Simon sp. & Araneae & Philodromidae & & & $x$ \\
\hline Trochosa ruricola (DeGeer) & Araneae & Lycosidae & $x$ & & \\
\hline Walckenaeria Blackwall sp. & Araneae & Linyphiidae & $\times$ & & $x$ \\
\hline Walckenaeria spiralis (Emerton) & Araneae & Linyphiidae & $\times$ & & $x$ \\
\hline
\end{tabular}


TABLE 1 (continued).

\begin{tabular}{|c|c|c|c|c|c|}
\hline & Order & Family & $\mathrm{PF}$ & ST & PL \\
\hline \multicolumn{6}{|l|}{ Chilopoda } \\
\hline Lithobiidae (sensu lato) (no further identification) & Lithobiomorpha & Lithobiidae & $x$ & & $x$ \\
\hline \multicolumn{6}{|l|}{ Insecta } \\
\hline Acupalpus Latreille sp. & Coleoptera & Carabidae & & $x$ & \\
\hline Agonum muelleri (Herbst) & Coleoptera & Carabidae & $x$ & & \\
\hline Agonum placidum (Say) & Coleoptera & Carabidae & $x$ & & \\
\hline Aleochara curtula (Goeze) & Coleoptera & Staphylinidae & & $\times$ & \\
\hline Aleochara gracilicornis Bernhauer & Coleoptera & Staphylinidae & & $\times$ & \\
\hline Aleochara Gravenhorst sp. & Coleoptera & Staphylinidae & $x$ & & $x$ \\
\hline Amara avida (Say) & Coleoptera & Carabidae & $\times$ & & \\
\hline Amara cupreolata Putzeys & Coleoptera & Carabidae & $x$ & $x$ & \\
\hline Amara impuncticollis (Say) & Coleoptera & Carabidae & $x$ & & \\
\hline Amphasia sericea (T.W. Harris) & Coleoptera & Carabidae & $x$ & & \\
\hline Anisodactylus sanctaecrucis (F.) & Coleoptera & Carabidae & $x$ & $x$ & \\
\hline Anotylus insecatus (Gravenhorst) & Coleoptera & Staphylinidae & $x$ & & \\
\hline Anotylus rugosus $(\mathrm{F})$. & Coleoptera & Staphylinidae & $x$ & $x$ & $x$ \\
\hline Anthicus cervinus LaFerté-Sénectère & Coleoptera & Anthicidae & $x$ & $x$ & $x$ \\
\hline Athetini (no further identification) & Coleoptera & Staphylinidae & $x$ & $x$ & $x$ \\
\hline Bembidion obscurellum (Motschulsky) & Coleoptera & Carabidae & $x$ & & \\
\hline Bembidion obtusum Audinet-Serville & Coleoptera & Carabidae & $x$ & & \\
\hline Bembidion quadrimaculatum oppositum Say & Coleoptera & Carabidae & $x$ & $x$ & \\
\hline Bembidion tetracolum Say & Coleoptera & Carabidae & $x$ & & \\
\hline Bembidion versicolor (LeConte) & Coleoptera & Carabidae & $x$ & & $x$ \\
\hline Brachinus Weber sp. & Coleoptera & Carabidae & $x$ & & \\
\hline Bradycellus congener (LeConte) & Coleoptera & Carabidae & $x$ & $x$ & $x$ \\
\hline Bradycellus rupestris (Say) & Coleoptera & Carabidae & $\times$ & $x$ & \\
\hline Carabus nemoralis O.F. Müller & Coleoptera & Carabidae & $\times$ & & \\
\hline Cerceris Latreille $\mathrm{sp}$. & Hymenoptera & Sphecidae & & $x$ & \\
\hline Chlaenius pusillus Say & Coleoptera & Carabidae & $x$ & & \\
\hline Chlaenius tricolor tricolor Dejean & Coleoptera & Carabidae & $x$ & & \\
\hline Chrysopa oculata Say & Neuroptera & Chrysopidae & $\times$ & $x$ & $x$ \\
\hline Chrysoperla carnea (Stephens) & Neuroptera & Chrysopidae & $x$ & $\times$ & $x$ \\
\hline Cicindela punctulata punctulata Olivier & Coleoptera & Cicindelidae & $\times$ & $x$ & \\
\hline Clivina impressefrons LeConte & Coleoptera & Carabidae & $x$ & & \\
\hline Coccinella septempunctata $\mathrm{L}$. & Coleoptera & Coccinellidae & $\times$ & $\times$ & $x$ \\
\hline Coleomegilla maculata lengi Tímberlake & Coleoptera & Coccinellidae & $x$ & $x$ & $x$ \\
\hline Colliuris pensylvanica (L.) & Coleoptera & Carabidae & $x$ & & \\
\hline Condylostylus caudatus (Wiedemann) & Diptera & Dolichopodidae & & $\times$ & \\
\hline Condylostylus sipho (Say) & Diptera & Dolichopodidae & & $x$ & \\
\hline Cordalia obscura (Gravenhorst) & Coleoptera & Staphylinidae & $x$ & & \\
\hline Cosmopepla bimaculata (Thomas) & Hemiptera & Pentatomidae & & & $x$ \\
\hline Crabronini (no further identification) & Hymenoptera & Sphecidae & & $x$ & \\
\hline Dolichopus acuminatus Loew & Diptera & Dolichopodidae & & $x$ & \\
\hline Dolichopus bifractus Loew & Diptera & Dolichopodidae & & $x$ & \\
\hline Drusilla canaliculata $(\mathrm{F})$. & Coleoptera & Staphylinidae & $x$ & & \\
\hline Elaphropus anceps (LeConte) & Coleoptera & Carabidae & $x$ & & \\
\hline Eupeodes Osten Sacken sp. & Diptera & Syrphidae & & $x$ & \\
\hline
\end{tabular}


TABLE 1 (continued).

\begin{tabular}{|c|c|c|c|c|c|}
\hline & Order & Family & PF & ST & PL \\
\hline Formica argentea W.M. Wheeler & Hymenoptera & Formicidae & $x$ & & \\
\hline Gabrius Curtis sp. & Coleoptera & Staphylinidae & $x$ & $x$ & \\
\hline Harmonia axyridis (Pallas) & Coleoptera & Coccinellidae & $x$ & & $x$ \\
\hline Harpalus affinis (Schrank) & Coleoptera & Carabidae & $x$ & & \\
\hline Harpalus compar LeConte & Coleoptera & Carabidae & $\times$ & & \\
\hline Harpalus pensylvanicus (DeGeer) & Coleoptera & Carabidae & $x$ & & \\
\hline Hippodamia glacialis glacialis $(\mathrm{F})$. & Coleoptera & Coccinellidae & & $x$ & \\
\hline Hippodamia parenthesis (Say) & Coleoptera & Coccinellidae & & $x$ & \\
\hline Hippodamia variegata (Goeze) & Coleoptera & Coccinellidae & & $x$ & $\times$ \\
\hline Hoplandria Kraatz sp. & Coleoptera & Staphylinidae & $\times$ & & \\
\hline Hoplandria lateralis (Melsheimer) & Coleoptera & Staphylinidae & & $x$ & \\
\hline Isohydnocera curtipennis (Newman) & Coleoptera & Cleridae & & $\times$ & \\
\hline Lasius F. sp. & Hymenoptera & Formicidae & $x$ & $x$ & $x$ \\
\hline Lathrobium Gravenhorst (sensu lato) sp. & Coleoptera & Staphylinidae & $x$ & $x$ & \\
\hline Lygus lineolaris (Palisot de Beauvois) & Hemiptera & Miridae & $x$ & $x$ & $x$ \\
\hline Malporus formicarius (LaFerté-Sénectère) & Coleoptera & Anthicidae & $x$ & & \\
\hline Meronera venustula (Erichson) & Coleoptera & Staphylinidae & $x$ & & \\
\hline Microlestes linearis (LeConte) & Coleoptera & Carabidae & $x$ & $x$ & \\
\hline Micromus Rambur sp. & Neuroptera & Hemerobiidae & $\times$ & & \\
\hline Mycetoporus Mannerheim sp. & Coleoptera & Staphylinidae & $x$ & & \\
\hline Myrmica Latreille sp. & Hymenoptera & Formicidae & $x$ & & \\
\hline Nabis americoferus Carayon & Hemiptera & Nabidae & $x$ & $x$ & $\times$ \\
\hline Neobisnius Ganglbauer sp. & Coleoptera & Staphylinidae & $x$ & & \\
\hline Neohypnus Coiffait and Saiz sp. & Coleoptera & Staphylinidae & $x$ & & \\
\hline Notiobia terminata (Say) & Coleoptera & Carabidae & & $x$ & \\
\hline Oxypoda Mannerheim sp. & Coleoptera & Staphylinidae & $\times$ & & \\
\hline Oxypselaphus pusillus (LeConte) & Coleoptera & Carabidae & $x$ & & \\
\hline Patrobus longicornis (Say) & Coleoptera & Carabidae & $x$ & & \\
\hline Philonthus carbonarius (Gravenhorst) & Coleoptera & Staphylinidae & $x$ & $x$ & \\
\hline Philonthus concinnus (Gravenhorst) & Coleoptera & Staphylinidae & $\times$ & $x$ & \\
\hline Philonthus Curtis sp. & Coleoptera & Staphylinidae & & & $x$ \\
\hline Philonthus lomatus Erichson & Coleoptera & Staphylinidae & & $\times$ & \\
\hline Philonthus varians (Paykull) & Coleoptera & Staphylinidae & $x$ & & \\
\hline Platycheirus Lepeletier and Serville sp. & Diptera & Syrphidae & & $x$ & \\
\hline Platycheirus quadratus (Say) & Diptera & Syrphidae & & $x$ & \\
\hline Poecilus chalcites (Say) & Coleoptera & Carabidae & $x$ & & \\
\hline Poecilus lucublandus lucublandus (Say) & Coleoptera & Carabidae & $x$ & & \\
\hline Polistes dominulus (Christ) & Hymenoptera & Vespidae & & $x$ & \\
\hline Polistes fuscatus (F.) & Hymenoptera & Vespidae & & $x$ & \\
\hline Pompilidae (no further identification) & Hymenoptera & Pompilidae & & $\times$ & \\
\hline Ponera pennsylvanica Buckley & Hymenoptera & Formicidae & $x$ & & \\
\hline Prenolepis imparis Say & Hymenoptera & Formicidae & $x$ & & \\
\hline Propylaea quatuordecimpunctata (L.) & Coleoptera & Coccinellidae & & $x$ & \\
\hline Psyllobora vigintimaculata (Say) & Coleoptera & Coccinellidae & & & $x$ \\
\hline Pterostichus melanarius (Illiger) & Coleoptera & Carabidae & $x$ & & \\
\hline Pterostichus permundus (Say) & Coleoptera & Carabidae & $x$ & & \\
\hline Scopaeus Erichson sp. & Coleoptera & Staphylinidae & $x$ & & \\
\hline Sphaerophoria asymmetrica Knutson & Diptera & Syrphidae & & $\times$ & \\
\hline
\end{tabular}


TABLE 1 (concluded).

\begin{tabular}{|c|c|c|c|c|c|}
\hline & Order & Family & $\mathrm{PF}$ & $\mathrm{ST}$ & PL \\
\hline Sphaerophoria contigua Macquart & Diptera & Syrphidae & & $x$ & $\bar{x}$ \\
\hline Sphaerophoria Lepeletier and Serville sp. & Diptera & Syrphidae & & $x$ & \\
\hline Stenistoderus rubripennis (LeConte) & Coleoptera & Staphylinidae & $x$ & & \\
\hline Stenolophus comma (F.) & Coleoptera & Carabidae & $\times$ & $x$ & $\times$ \\
\hline Stenolophus ochropezus (Say) & Coleoptera & Carabidae & & $x$ & \\
\hline Stenus Latreille sp. & Coleoptera & Staphylinidae & $x$ & & $x$ \\
\hline Syrphus vitripennis Meigen & Diptera & Syrphidae & & $x$ & \\
\hline Tachyporus Gravenhorst sp. & Coleoptera & Staphylinidae & $x$ & & \\
\hline Tachyporus maculicollis LeConte & Coleoptera & Staphylinidae & & $x$ & \\
\hline Tachyporus nitidulus (F.) & Coleoptera & Staphylinidae & $x$ & & \\
\hline Tetragonoderus fasciatus (Haldeman) & Coleoptera & Carabidae & $\times$ & & \\
\hline Tinotus Sharp sp. & Coleoptera & Staphylinidae & $\times$ & & \\
\hline Toxomerus geminatus (Say) & Diptera & Syrphidae & & $x$ & \\
\hline Toxomerus marginatus (Say) & Diptera & Syrphidae & & $\times$ & $x$ \\
\hline Trechus quadristriatus (Schrank) & Coleoptera & Carabidae & $x$ & & $x$ \\
\hline Vespula germanica (F.) & Hymenoptera & Vespidae & & $x$ & \\
\hline Vespula maculifrons (Buysson) & Hymenoptera & Vespidae & & $x$ & \\
\hline Vespula vidua (Saussure) & Hymenoptera & Vespidae & & $x$ & \\
\hline Xantholinus linearis (Olivier) & Coleoptera & Staphylinidae & $x$ & & \\
\hline
\end{tabular}

NoтE: Pitfall and sticky traps were placed in three plots in 1995 and in two plots in 1996. Plant samples were taken in two plots in 1996 only. " $x$ " indicates presence in the sample.

formicum (Arachnida) and Meioneta unimaculata (Arachnida) captured in 1996 came mostly from the first two sampling dates (Fig. 2C). In 1995, trapping started later, and the peak periods of activity for these two species may have been missed. The large number of Bembidion quadrimaculatum caught in 1995 showed a clear peak in midseason, but the pattern was not repeated in the 1996 plots (Fig. 3A). In both years, E. anceps activity was highest early and declined later in the season (Fig. 3A). Clear seasonal trends were not evident for the remaining Carabidae (Fig. 3A), nor for the most numerous Staphylinidae (Fig. 3B), Anthicidae (Fig. 3C), or Formicidae (Fig. 3C).

Substantial rainfall during the trapping periods on 3 July $(10 \mathrm{~mm})$ and 31 July (20 $\mathrm{mm})$ in 1996 appeared to reduce the trap catch of some of the arthropods [e.g., Pardosa sp. (Fig. 2B), Tennesseellum formicum and Meioneta unimaculata (Fig. 2C), and several of the carabid species (Fig. 3A)]. Lesser amounts of rain on 28 June 1995 $(2.5 \mathrm{~mm}), 5$ July $1995(8 \mathrm{~mm})$, and 19 June $1996(4 \mathrm{~mm})$ may have affected trap catches as well, although the effects are not as clear. It was observed that although covers were used over the traps, heavy rains sometimes left droplets of mud splashed on the sides of the cups that may have provided sufficient foothold for some of the predators to escape from the traps.

Sticky Traps. In general, fewer taxa and fewer individuals were captured in the sticky traps than in the pitfall traps (Table 1 and Fig. 4). As with the pitfall traps, the great majority of taxa were represented by only a few individuals. Lygus lineolaris (Insecta), Stenolophus comma, and Coleomegilla maculata lengi (Insecta) were relatively numerous in both years. Adult Toxomerus marginatus (Insecta) and Condylostylus sp. (Insecta) were present but not monitored in 1995, and were the most abundant taxa in the traps in 1996. In 1995, some large differences between plots were evident, with Lygus lineolaris and Phalangium opilio being more abundant and Stenolophus comma and Coleomegilla maculata being less abundant in the relatively weedy plot 1 than in 

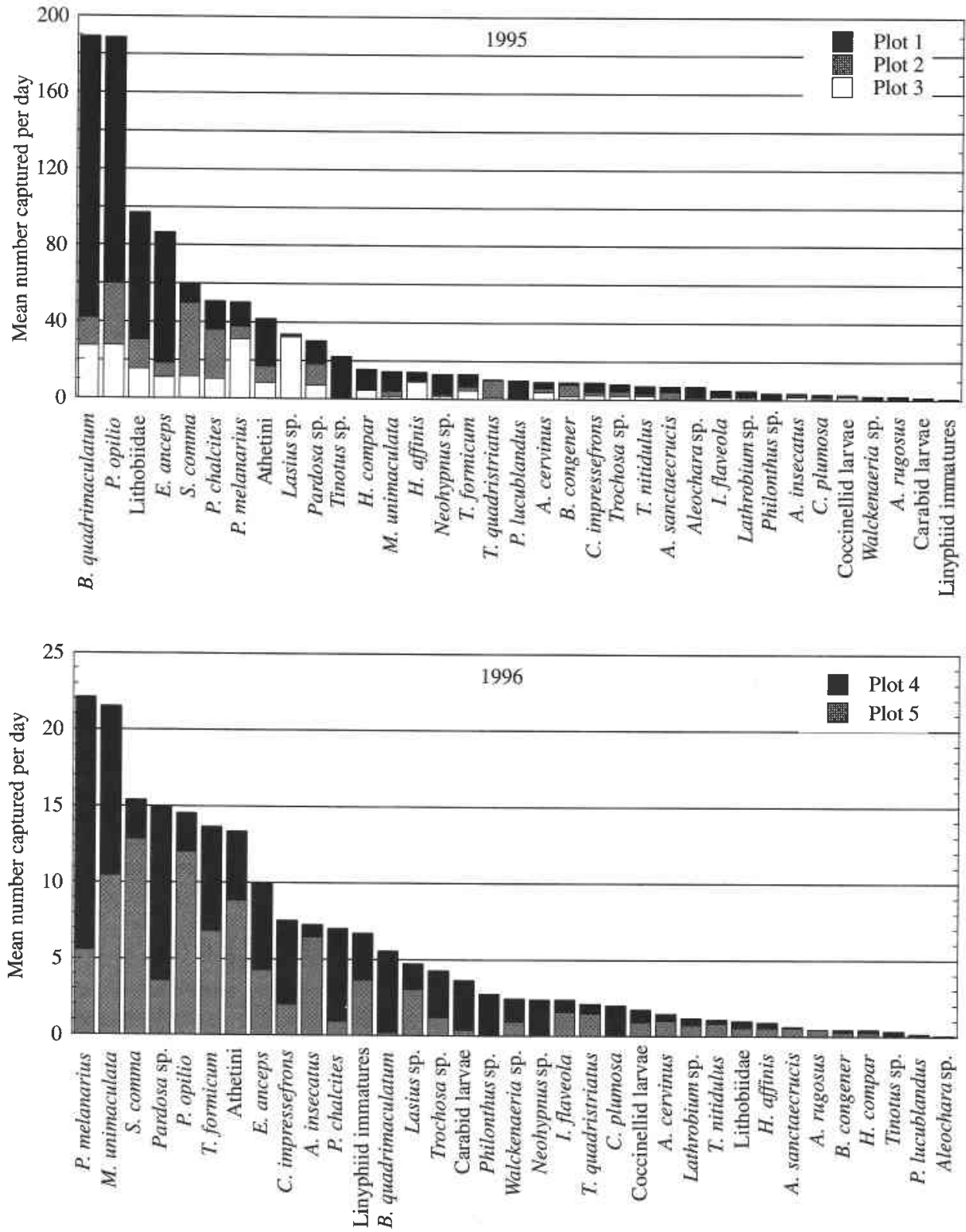

FIGURE 1. Mean number of predatory arthropods captured per day in pitfall traps in 1995 and 1996. Figure includes only groups for which total captures were $\mathbf{3 2 0}$.

the other two plots (Fig. 4). Trap catches of the most abundant taxa were more evenly distributed between the relatively weed-free plots 2 and 3 in 1995 and the two 1996 plots. The only clear seasonal trend in the sticky-trap catches was the early season buildup and midseason drop-off in numbers of Toxomerus marginatus in 1996 (Fig. 5).

Plant Sampling. Except for the spiders, taxonomic diversity was substantially less overall in the plant samples than in the pitfall or sticky traps (Table 1). Spiders were the 


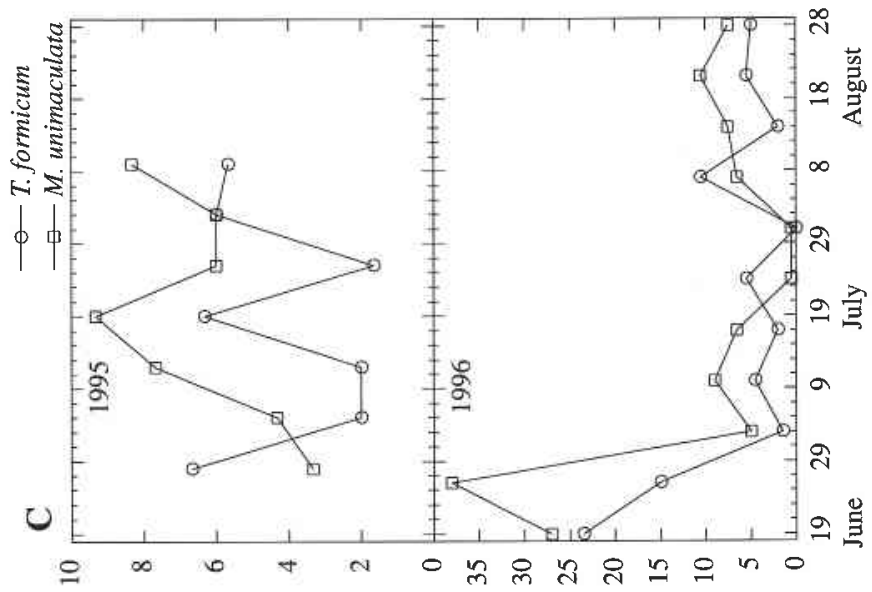



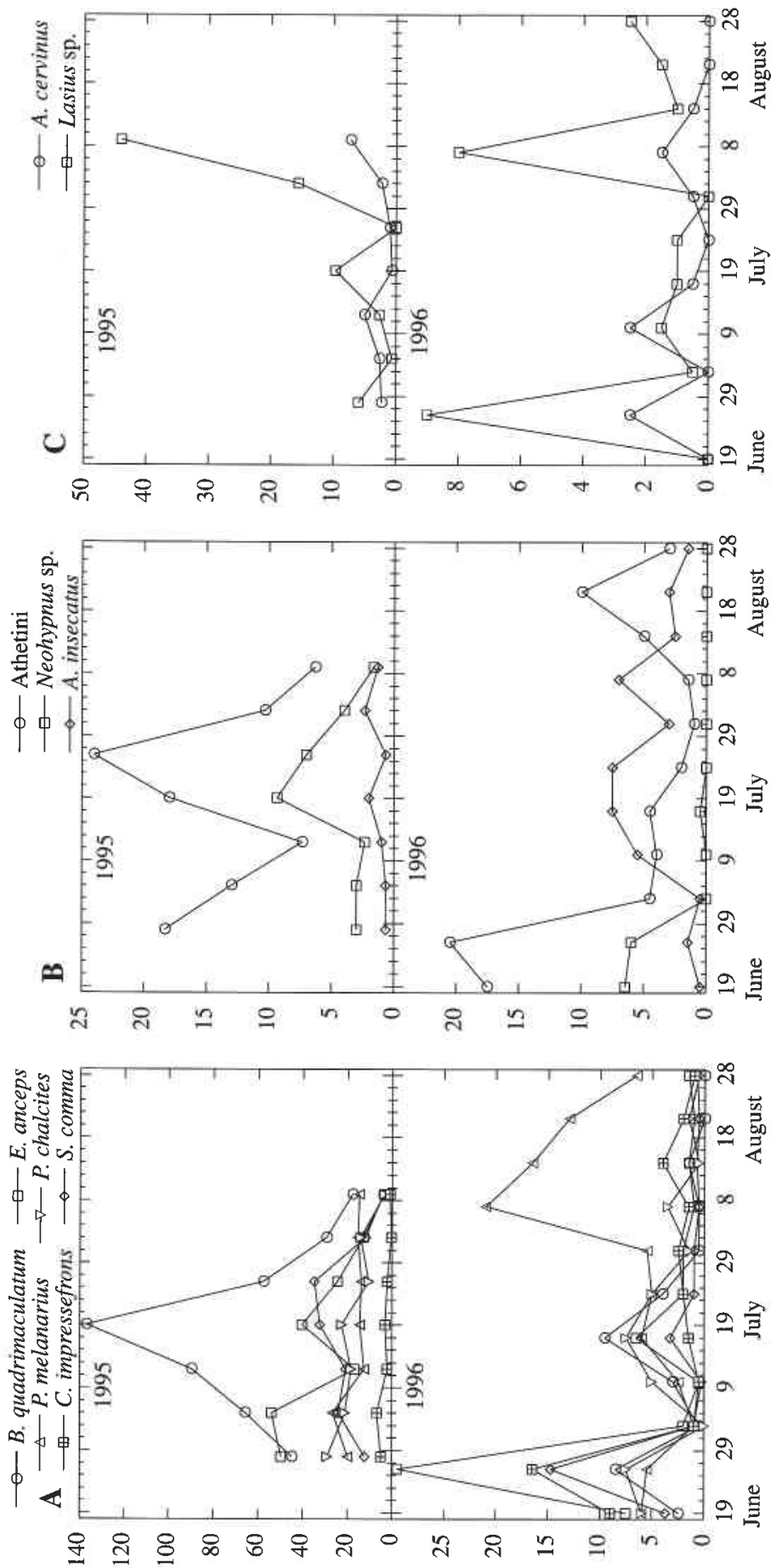

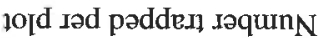




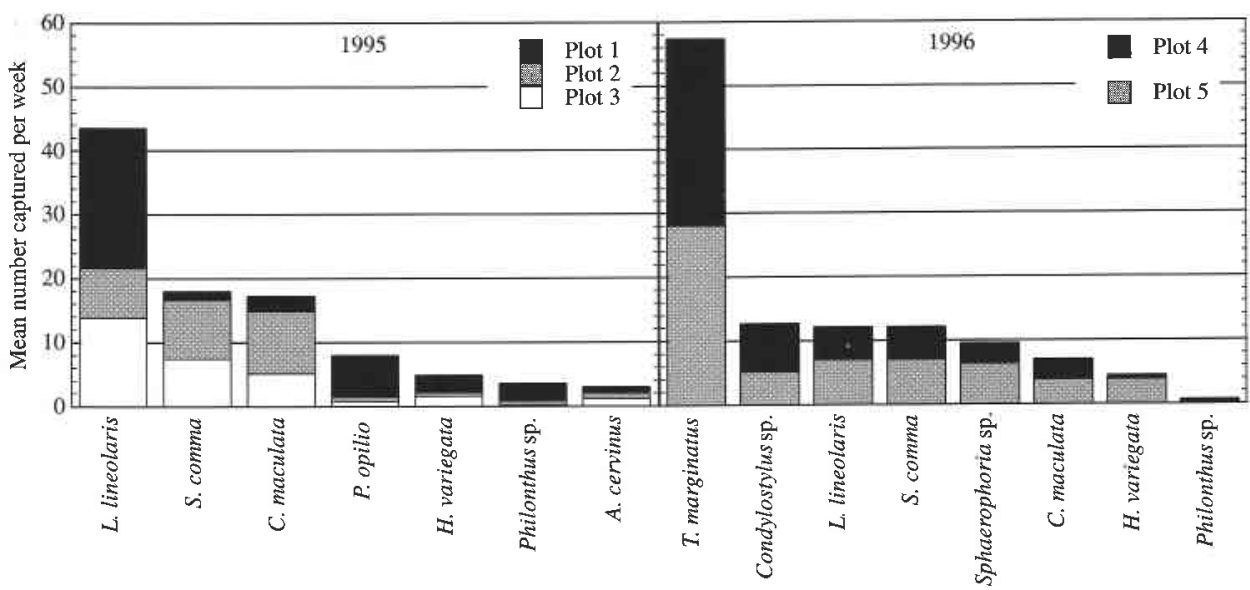

Figure 4. Numbers of most abundant predatory arthropods captured on sticky traps on cabbage plants, adjusted to number captured per week for five plots in 1995 and 1996. Figure includes only taxa for which total captures were $\geq 15$. Note: Condylostylus sp., Toxomerus marginatus, and Sphaerophoria sp. were not monitored in 1995. No Phalangium opilio or Anthicus cervinus were caught on the traps in 1996.

most abundant group, comprising 54\% of the predatory arthropods collected. Densities were low, however, averaging 0.2 spiders per plant. Most $(74 \%)$ of the spiders were immatures but, in most cases, could be identified at least to family level. Of those spiders that could be determined to family level ( $91 \%$ of the total), $71 \%$ were linyphiids. Among the 51 adult spiders collected in the plant samples, the most numerous species were Meioneta unimaculata (25\%) and Tennesseellum formicum (20\% of the adults). The numbers of none of the other species reached $8 \%$ of the total adults collected.

Syrphid (Insecta) larvae were the most abundant predatory-insect group in the plant samples, accounting for $13 \%$ of the total predators and averaging 0.03 individuals per plant. Syrphid pupae were also collected, and nine of these pupae were reared to adults, yielding one specimen of Sphaerophoria contigua and eight of Toxomerus marginatus. Coccinellid larvae and adults comprised $12 \%$ of the total predators collected (mean of 0.02 per plant) and consisted mainly of Coleomegilla maculata $(77 \%)$, of which $47 \%$ were larvae. A total of 180 coccinellid eggs was also found on the sample plants. Nymphs comprised $78 \%$ of the Lygus lineolaris collected in the plant samples; all the nymphs were found on the final sampling date. Altogether, Lygus lineolaris made up $10 \%$ of the arthropod predators in the plant samples and averaged 0.02 per plant.

Because the numbers of each taxon collected at each sampling time were low, statistical tests were not useful in evaluating the effect of time of day on predator abundance on the plants. Graphical examination of the data revealed that the time of day at which a sample was collected had no clear consistent effect on the counts of the most abundant taxa found in the plant samples. No pronounced seasonal trends were evident either, except perhaps a general tendency for numbers to increase over the course of the season.

Predation in Small Arenas. All the species tested in the small arenas, except Meioneta unimaculata, fed on Pieris rapae to some extent (Table 2). Both male and female Meioneta unimaculata formed sheet webs in the containers. Only three of the 62 Anthicus cervinus (Insecta) fed at all, one on an egg and two on larvae. Several species showed a greater tendency to feed on larvae than on eggs. The 19 Pardosa milvina 

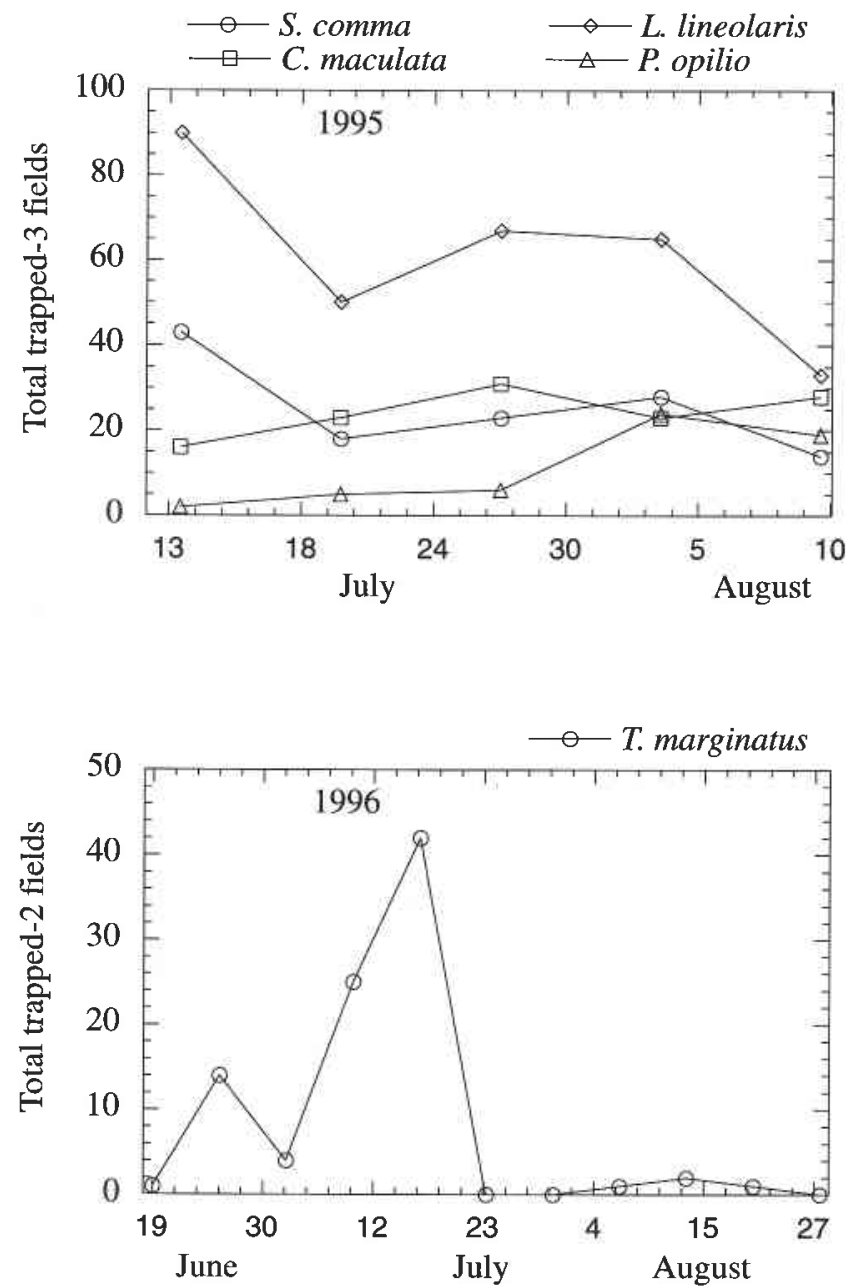

FigURE 5. Total catch on sticky traps by date for the most abundant predatory arthropods in 1995 and 1996. Dates given in the 1995 plot are midpoints of each 7-d trapping period. In 1996, trapping was conducted only during 24-h periods starting at approximately 08:00 on the dates indicated.

(Arachnida) tested with Pieris rapae eggs did not consume any, but almost all those presented with first instars fed on the larvae. At least some of the Nabis americoferus (Insecta), Orius insidiosus (Say) (Coleoptera: Anthocoridae), and Hippodamia variegata (Insecta) fed on eggs, but all showed a much greater tendency to feed on larvae.

Predation on Cabbage Plants in the Laboratory. Stenolophus comma and Lygus lineolaris did not feed on larval Pieris rapae on the plants, but the other species tested did (Table 3). Stenolophus comma formed deep burrows in the substrate. Lygus lineolaris stayed mostly on the plants and some were observed feeding on the plants. Pardosa milvina and $O$. insidiosus consumed, on average, $<1$ larva per cage. Larval Pieris rapae were apparently much less vulnerable to these predators when on plants than when on leaf disks in the small-arena experiments. Although Phalangium opilio, N. americoferus, Coleomegilla maculata, and Hippodamia variegata all consumed some of the larvae on the plants, in all cases many larvae survived the experiment despite the 
TABLe 2. Consumption of Pieris rapae eggs and first instars by predators in small arenas.

\begin{tabular}{|c|c|c|c|c|c|c|c|c|c|c|}
\hline \multirow[b]{2}{*}{ Predator species } & \multicolumn{5}{|c|}{ Predation on eggs } & \multicolumn{5}{|c|}{ Predation on first instars } \\
\hline & $n$ & $\begin{array}{c}\text { No. of eggs } \\
\text { provided }\end{array}$ & $\begin{array}{l}\text { No. of eggs } \\
\text { consumed } \\
\text { (mean } \pm \text { SE) }\end{array}$ & $\begin{array}{c}\text { Percent } \\
\text { consuming } \\
\geq 1 \text { egg }\end{array}$ & $\begin{array}{l}\text { Maximum } \\
\text { consumption }\end{array}$ & $n$ & $\begin{array}{c}\text { No. of larvae } \\
\text { provided }\end{array}$ & $\begin{array}{c}\text { No. of larvae } \\
\text { consumed } \\
\text { (mean } \pm \mathrm{SE} \text { ) }\end{array}$ & $\begin{array}{l}\text { Percent } \\
\text { consuming } \\
\geq 1 \text { larva }\end{array}$ & $\begin{array}{c}\text { Maximum } \\
\text { consumption }\end{array}$ \\
\hline Meioneta unimaculata* & 21 & 10 & 0.00 & 0 & 0 & 23 & 5 & 0.00 & 0 & 0 \\
\hline Pardosa milvina* & 19 & 10 & 0.00 & 0 & 0 & 66 & 5 & $3.50 \pm 0.22$ & 92 & 5 \\
\hline Phalangium opilio* & 43 & 20 & $12.63 \pm 1.24$ & 84 & 20 & 49 & 5 & $2.94 \pm 0.25$ & 88 & 5 \\
\hline Lygus lineolaris ${ }^{\dagger}$ & 20 & 10 & $3.25 \pm 1.03$ & 40 & 10 & 23 & 5 & $0.65 \pm 0.21$ & 43 & 4 \\
\hline Nabis americoferus ${ }^{\dagger}$ & 20 & 10 & $4.15 \pm 1.06$ & 50 & 10 & 22 & 5 & $4.36 \pm 0.21$ & 100 & 5 \\
\hline Orius insidiosus ${ }^{\dagger}$ & 23 & 10 & $0.09 \pm 0.06$ & 9 & 1 & 29 & 5 & $2.38 \pm 0.26$ & 86 & 5 \\
\hline Stenolophus comma ${ }^{\dagger}$ & 20 & 20 & $13.90 \pm 2.07$ & 75 & 20 & 22 & 5 & $4.00 \pm 0.38$ & 86 & 5 \\
\hline Coleomegilla maculata ${ }^{4}$ & 20 & 10 & $5.95 \pm 1.10$ & 65 & 10 & 23 & 5 & $4.26 \pm 0.32$ & 96 & 5 \\
\hline Hippodamia variegata ${ }^{\dagger}$ & 23 & 10 & $0.26 \pm 0.26$ & 4 & 6 & 21 & 5 & $1.76 \pm 0.45$ & 57 & 5 \\
\hline Anthicus cervinus ${ }^{\dagger}$ & 35 & 20 & $0.03 \pm 0.03$ & 3 & 1 & 27 & 5 & $0.07 \pm 0.05$ & 7 & 1 \\
\hline
\end{tabular}

NoTE: Number consumed includes partially as well as completely consumed individual prey.

*Arachnida.

†Insecta. 
TABLE 3. Consumption of first instar Pieris rapae on potted cabbage plants by groups of predators.

\begin{tabular}{|c|c|c|}
\hline Species & No. of predators/plant* & $\begin{array}{l}\text { No. of Pieris rapae consumed } \\
\text { (mean } \pm \text { SE) }\end{array}$ \\
\hline Pardosa milvina ${ }^{\dagger}$ & 10 & $0.90 \pm 0.38$ \\
\hline Phalangium opilio $^{\dagger}$ & 4 & $5.60 \pm 0.72$ \\
\hline Lygus lineolaris ${ }^{\ddagger}$ & 6 & 0.00 \\
\hline Nabis americoferus ${ }^{\star}$ & 6 & $6.11 \pm 0.81$ \\
\hline Orius insidiosus ${ }^{\ddagger}$ & 10 & $0.90 \pm 0.31$ \\
\hline Stenolophus comma ${ }^{\ddagger}$ & 6 & 0.00 \\
\hline Coleomegilla maculata & 6 & $5.70 \pm 1.07$ \\
\hline Hippodamia variegata & 6 & $5.60 \pm 0.65$ \\
\hline
\end{tabular}

Note: Ten $P$. rapae were placed on each plant initially. For $N$. americoferus, $n=9$ plants; for all others, $n=$ 10 plants.

*Some predators died during the course of the experiment, as follows: $P$, opilio, $1 / 40 ; L$. lineolaris, $9 / 60$;

N. americoferus, $5 / 54 ;$ C. maculata, $1 / 60$.

${ }^{\dagger}$ Arachnida.

${ }_{\text {tInsecta. }}$.

high densities of predators in the cages. Although a few predators died during the experiments, there was no evidence of cannibalism, except for one Phalangium opilio that was found partially consumed.

\section{Discussion}

Predators Occurring in Cabbage Fields. Our intensive trapping and sampling revealed a diverse array of arthropod predators occurring in cabbage fields. This information will serve as a foundation for future studies of the ecological roles of naturally occurring arthropod predators found in cabbages in New York State and their effects on cabbage pests. Only a few predator species, however, appeared to occur in numbers high enough to have the potential to significantly affect populations of cabbage pests, whereas the vast majority of species appear to be relatively rare.

In many cases, the numbers of the most abundant and active predators varied substantially according to plot, year, or date. Such variation could present problems for growers seeking to increase reliance on predators to help reduce Pieris rapae and other pests in their fields. More extensive monitoring across many sites, over several years, and throughout the cabbage growing season would help delineate the range of such variation and provide clues to the factors causing it. Outbreaks of Pieris rapae can occur in the cabbage fields at almost any time during the periods we sampled (Shelton et al. 1983b; AM Shelton, unpublished data).

Predators Occurring on Cabbage Plants in the Field. Many of the species that appear, from pitfall-trapping, to be abundant in the ground fauna seem to be rare or absent on plants, as shown by the results of sticky-trapping and plant-sampling. Because larval Pieris rapae rarely leave suitable host plants before dispersing to pupate (Harcourt 1961; Jones 1977), ground dwelling predators that do not forage on cabbage plants would likely have little direct effect on populations of larval Pieris rapae in the crop. Centipedes, Trochosa ruricola (Arachnida), most of the Carabidae, and many of the Staphylinidae, as well as the species of Formicidae collected in our study seem to fall into this category. Relatively common species that occurred both on the ground and on 
plants included Stenolophus comma, Meioneta unimaculata, Tennesseellum formicum, Phalangium opilio, Philonthus spp., and A. cervinus. Lygus lineolaris and species of the Syrphidae and Coccinellidae were found primarily or solely on plants.

For many of the species that occur both on plants and on the soil surface, pitfalltrapping may be a more effective monitoring tool than either sticky-trapping or plantsampling. The larger numbers of predatory arthropods collected by pitfall-trapping could indicate that these predators tend to be more active or abundant on the ground than on plants. Alternatively, they could simply be more susceptible to collection by pitfall traps than by the other two methods. Because of the differences in the sampling methods used for foliar and ground-dwelling fauna, it is not possible to make precise inferences about the relative numbers and activity of the different species occurring on plants and on the ground. The results confirm the importance of using multiple sampling methods to study arthropod predator faunas in crops.

Predator Foraging on Cabbage Plants. The occurrence of a species on plants does not necessarily indicate that it searches for prey there. For example, ground-foraging predators may climb plants before taking flight to disperse (e.g., Dennis and Sotherton 1994) and spiders often ascend plants or other objects for ballooning (Comstock 1940). Dispersing ground dwellers may also alight on plants haphazardly before finding their way to the soil surface. The laboratory feeding trials with potted plants were intended to identify those species that actively seek food on cabbage plants. Stenolophus comma was relatively abundant in pitfall and sticky traps, occurred in low numbers in the plant samples, and fed readily on Pieris rapae in the small arenas; however, no feeding was observed when Stenolophus comma were offered Pieris rapae on cabbage plants. Stenolophus comma fly readily and are attracted to lights in large numbers on warm humid summer nights (Kirk 1975; Wyman et al. 1976; Pausch 1979). We suspect that the beetles we found in the sticky traps on cabbage leaves and in plant samples may have been dispersing rather than foraging.

All but two of the species tested for predation on potted plants consumed some of the larvae presented. Despite the high densities of predators used, in every case, many of the Pieris rapae escaped predation for the duration of the experiment. Observation of the predators' movements on the plants revealed that many had difficulty gaining sufficient foothold to search all parts of the plants. It appears that areas on the undersides of the leaf far from the leaf veins and leaf edges may be essentially inaccessible to these predators, probably leaving Pieris rapae that feed in these areas safe from them. Shah (1982) and Grevstad and Klepetka (1992), working with coccinellids, and Eigenbrode et al. (1996), working with coccinellids, anthocorids, and chrysopids, made similar observations on these predators' difficulties in foraging on crucifers with thick cuticular waxes. Experiments should be conducted with syrphid larvae and hunting linyphiids as well, to determine if the cuticular wax and other aspects of cabbage morphology similarly restrict foraging of these types of predators. We were unable to obtain sufficient numbers of either to conduct laboratory predation assays in small arenas or on potted plants.

Linyphiidae and Syrphidae. Linyphiidae were the most abundant predatory arthropods in the plant samples. The only linyphiid tested in the feeding assays, Meioneta unimaculata, formed sheet webs and did not feed on Pieris rapae eggs or first instars. Although the linyphiids are generally known as sheet-web weavers (Nyffeler et al. 1994), the large number of linyphiids - including Meioneta unimaculata-collected in our pitfall traps indicates that these spiders not only reside in webs awaiting prey, but also spend time wandering about. Others have noted that male linyphiids often 
predominate in pitfall-trap catches (e.g., Thornhill 1983), suggesting that mate searching, rather than foraging, may be the primary activity of many of the individuals captured in pitfall traps. We did not enumerate the spiders we captured by sex, but did note substantial numbers of females in the catch (MA Schmaedick, unpublished data). Further investigation could help determine if this movement by males and females is solely for dispersal or mate finding or whether it also includes foraging. Spiders that actively hunt for their prey would be expected to be much more likely to encounter and prey upon the slow moving larval Pieris rapae than those that rely on webs.

Syrphid larvae were also relatively abundant in the plant samples, and adults of this taxon were the most numerous in the 1996 sticky-trap samples. Syrphids were not tested in our laboratory experiments, but researchers working on brussels sprouts, Brassica oleracea var. gemmifera D.C., in England (Dempster 1967) and cabbage in New Zealand (Ashby 1974) have found syrphids to be important predators of Pieris rapae in these countries. If sufficient numbers of local syrphid species can be obtained, perhaps through rearing, then laboratory experiments to evaluate their foraging ability on cabbage could help to elucidate their role in cabbages in New York State.

Lygus lineolaris in Cabbage: Friend or Foe? Lygus lineolaris occurred primarily on plants in the cabbage field and were observed to climb readily on the potted plants in the laboratory trial; however, they did not consume any of the larval Pieris rapae from the plants, although $43 \%$ of Lygus lineolaris fed on larval Pieris rapae in small arenas. Although Lygus lineolaris is regarded primarily as a plant feeder and a pest in many crops, it is not considered a pest of cabbages in New York State. There is at least one published observation of apparent Lygus lineolaris predation on larval Pieris rapae on collards, Brassica oleracea var. acephala (Culliney et al. 1986), and Parker (1970) reported that an unspecified Lygus sp. fed on Pieris rapae eggs and larvae in plantings of mixed Brassica spp. Cleveland (1987) described predation by Lygus lineolaris on Heliothis virescens (F.) (Lepidoptera: Noctuidae) eggs and larvae on caged cotton plants in a greenhouse. Numerous reports of predation by Lygus spp. were reviewed by Wheeler (1976), who concluded that Lygus spp. may, in certain situations, be more beneficial through their roles as predators than they are harmful as plant feeders. The behaviour of Lygus lineolaris under our experimental conditions may differ from that under field conditions.

Other Predators. Our sampling and trapping procedures neglected two taxa in particular that may have roles in reducing Pieris rapae populations: predatory mites and wasps. Mites were not monitored in our plots but were occasionally seen in pitfall traps or on plants and have been observed to prey on Pieris rapae eggs or larvae in other studies (Richards 1940; Parker 1970; Yamamoto 1981; Jones et al. 1987). Although a few vespids were caught on the sticky traps, the trapping and sampling methods we used were not designed to measure levels of vespid abundance or activity. Both Polistes spp. (Insecta), and Vespula spp. (Insecta) have been observed to prey on larval Pieris rapae (Richards 1940; Sutherland 1966; Parker 1970; Hasui 1977; Jones and Ives 1979; Gould and Jeanne 1984); both were frequently seen foraging in our plots.

Conclusions. Although important questions remain, this study has succeeded in documenting some of the diversity of predatory arthropods found in cabbages in New York State and in identifying a set of species that are likely to be effective predators of Pieris rapae in New York State cabbage fields. These species were relatively abundant, occurred on cabbage plants in the field, fed readily on eggs and larvae of Pieris rapae, and foraged for prey on cabbage plants. Conversely, we have also shown that many of the arthropod predators found in cabbage fields lack one or more of these attributes and are 
therefore unlikely to play a significant or direct role in Pieris rapae dynamics in the crop. Based on our study, species that merit further investigation as potential Pieris rapae predators include Pardosa milvina, Phalangium opilio, Coleomegilla maculata, and Hippodamia variegata. All four species occurred on cabbage foliage in the field and, in the laboratory, fed readily on Pieris rapae eggs and first instars, both in small arenas and on plants. Although $N$. americoferus and $O$. insidiosus preyed on Pieris rapae in the laboratory, they will have little effect in the area of New York State unless their numbers in cabbage fields can be increased. In contrast, A. cervinus, while often abundant, showed a low propensity to feed on Pieris rapae and, thus, it appears unlikely that it would have a substantial effect in the field. Several species of Syrphidae and Linyphiidae were relatively abundant on plants in the field but remain to be tested for their foraging ability and propensity to feed on Pieris rapae. Vespid wasps and mites, important predators on Pieris rapae in other areas, were not evaluated in this study, athough both were present in the fields. For Lygus lineolaris, additional studies are required to clarify the conditions under which it is predaceous and whether its potential role as a predator in cabbage will outweigh its role as a pest.

Our results provide valuable information on the diversity and relative abundance and activity of predatory arthropods in cabbage fields and show which of the many predatory arthropods occurring there are most likely to be effective predators of Pieris rapae. Future efforts should focus on further elucidating the roles of these species in Pieris rapae population dynamics and on developing ways to maximize their impact on the cabbage crop.

\section{Acknowledgements}

The authors thank Rick Piccioni, Mary Balsley, Linda Baube, Steve Barry, Bill Wilsey, and Juliet Tang for technical assistance. We are grateful for the generous help with identification provided by John Ascher, Rick Hoebeke, Jonathan Mawdsley, Michael McDonald, Catherine Tauber, Xinping Wang, and Kip Will of Cornell University; Charles Dondale, Ales Smetana, and Richard Vockeroth of Agriculture Canada; Robert Davidson of the Carnegie Museum; Donald Chandler of the University of New Hampshire; Daniel Bickel of the Australian Museum; John Dobyns of Neenah, Wisconsin; and James Cockendolpher of Lubbock, Texas. We also thank Jan Nyrop and Michael Hoffmann for reviewing early versions of the manuscript and Marina Caillaud and Cathy Heidenreich for assistance with the French abstract. This research was supported in part by the New York State Integrated Pest Management Program.

\section{References}

Ashby JW. 1974. A study of arthropod predation of Pieris rapae L. using serological and exclusion techniques. Journal of Applied Ecology 11: 419-25

Cleveland TC. 1987. Predation by tamished plant bugs (Heteroptera: Miridae) of Heliothis (Lepidoptera: Noctuidae) eggs and larvae. Environmental Entomology 16: 37-40

Comstock JH. 1940. The spider book. Rev. ed., WJ Gertsch (Ed.). New York: Doubleday, Doran, and Co.

Courtney SP. 1986. The ecology of pierid butterflies: dynamics and interactions. Advances in Ecological Research 15: 51-131

Culliney TW, Pimentel D, Namuco OS, Capwell BA. 1986. New observations of predation by plant bugs (Hemiptera: Miridae). The Canadian Entomologist 118: 729-30

Dempster JP. 1967. The control of Pieris rapae with DDT. I. The natural mortality of the young stages of Pieris. Journal of Applied Ecology 4: 485-500

1984. The natural enemies of butterflies. pp. 97-104 in RI Vane-Wright, PR Ackery (Eds.), The biology of butterflies. New York: Academic Press

Dennis P, Sotherton NW. 1994. Behavioural aspects of staphylinid beetles that limit their aphid feeding potential in cereal crops. Pedobiologia 38: 222-37 
Ehrlich PR. 1984. The structure and dynamics of butterfly populations. pp. 25-40 in RI Vane-Wright, PR Ackery (Eds.), The biology of butterflies. New York: Academic Press

Eigenbrode SD, Castagnola T, Roux M-B, Steljes L. 1996. Mobility of three generalist predators is greater on cabbage with glossy leaf wax than on cabbage with a wax bloom. Entomologia Experimentalis et Applicata 81: 335-43

Fagan WF, Hakim AL, Ariawan H, Yuliyantiningsih S. 1996. Interactions between biological control efforts and insecticide applications in tropical rice agroecosystems: the potential role of intraguild predation. Biological Control 13: 121-6

Gilbert LE, Singer MC. 1975. Butterfly ecology. Annual Review of Ecology and Systematics 6: 365-97

Gould WP, Jeanne RL. 1984. Polistes wasps (Hymenoptera: Vespidae) as control agents for lepidopterous cabbage pests. Environmental Entomology 13: 150-6

Grevstad FS, Klepetka BW. 1992. The influence of plant architecture on the foraging efficiencies of a suite of ladybird beetles feeding on aphids. Oecologia 92: 399-404

Harcourt DG. 1961. Spatial pattern of the imported cabbageworm, Pieris rapae (L.) (Lepidoptera: Pieridae), on cultivated cruciferae. The Canadian Entomologist 93: 945-52

Hasui H. 1977. On the seasonal variability of survivorship curves and life tables of Pieris rapae crucivora Boiduval (Lepidoptera: Pieridae). [In Japanese.] Japanese Journal of Ecology 27: 75-82

Jones RE. 1977. Search behaviour: a study of three caterpillar species. Behaviour 60: 237-59 1981. The cabbage butterfly, Pieris rapae (L.): 'a just sense of how not to fly'. pp. 217-28 in RL Kitching, RE Jones (Eds.), The ecology of pests: some Australian case histories. Melbourne: CSIRO

Jones RE, Ives PM. 1979. The adaptiveness of searching and host selection behaviour in Pieris rapae (L.). Australian Journal of Ecology 4: 75-86

Jones RE, Nealis VG, Ives PM, Scheermeyer E. 1987. Seasonal and spatial variation in juvenile survival of the cabbage butterfly Pieris rapae: evidence for patchy density-dependence. Journal of Animal Ecology 56: 723-37

Kirk VM. 1975. Biology of Stenolophus (= Agonoderus) comma, a ground beetle of cropland. Annals of the Entomological Society of America 68: $135-8$

Lokkers C, Jones RE. 1999. The cabbage white, Pieris rapae (Pieridae). pp. 153-72 in RL Kitching, E Scheermeyer, RE Jones, NE Pierce (Eds.), Biology of Australian butterflies. Collingwood, Victoria, Australia: CSIRO

Losey JE, Denno RF. 1998a. Positive predator-predator interactions: enhanced predation rates and synergistic suppression of aphid populations. Ecology 79: 2143-52

$1998 \mathrm{~b}$. The escape response of pea aphids to foliar-foraging predators: factors affecting dropping behaviour. Ecological Entomology 23: 53-61

Nyffeler M, Sterling WL, Dean DA. 1994. How spiders make a living. Environmental Entomology 23: 135767

Oatman ER, Platner GR. 1969. An ecological study of insect populations on cabbage in southem California. Hilgardia 40: $1-40$

Parker FD. 1970. Seasonal mortality and survival of Pieris rapae (Lepidoptera: Pieridae) in Missouri and the effect of introducing an egg parasite, Trichogramma evanescens. Annals of the Entomological Society of America 63: 985-94

Pausch RD. 1979. Observations on the biology of the seed com beetles, Stenolophus comma and Stenolophus lecontei. Annals of the Entomological Society of America 72: 24-8

Polis GA, Myers CA. 1989. The ecology and evolution of intraguild predation: potential competitors that eat each other. Annual Review of Ecology and Systematics 20: 297-330

Richards OW. 1940. The biology of the small white butterfly (Pieris rapae), with special reference to the factors controlling its abundance. Journal of Animal Ecology 9: 243-88

Rosenheim JA. 1998. Higher-order predators and the regulation of insect herbivore populations. Annual Review of Entomology 43: 421-47

Rosenheim JA, Kaya HK, Ehler LE, Marois JJ, Jaffee BA. 1995. Intraguild predation among biologicalcontrol agents: theory and evidence. Biological Control 5: 303-35

Schmaedick MA, Shelton AM. 1999. Experimental evaluation of arthropod predation on Pieris rapae (Lepidoptera: Pieridae) eggs and larvae in cabbage. Environmental Entomology 28: 439-44

Settle WH, Ariawan H, Astuti ET, Cahyana W, Hakim AL, Hindayana D, Lestari AS, Pajarningsih, Sartanto. 1996. Managing tropical rice pests through conservation of generalist natural enemies and alternative prey. Ecology 77: 1975-88

Shah MA. 1982. The influence of plant surfaces on the searching behaviour of coccinellid larvae. Entomologia Experimentalis et Applicata 31: $377-80$

Shelton AM, Andaloro JT, Hoy CW. 1983a. Survey of ground-dwelling predaceous and parasitic arthropods in cabbage fields in upstate New York. Environmental Entomology 12: 1026-30

Shelton AM, Sears MK, Wyman JA, Quick TC. 1983b. Comparison of action thresholds for lepidopterous larvae on fresh-market cabbage. Journal of Economic Entomology 76: 196-9 
Snyder WE, Wise DH. 1999. Predator interference and the establishment of generalist predator populations for biocontrol. Biological Control 15: 283-92

Sutherland DWS. 1966. Biological investigations of Trichoplusia ni (Hübner) and other Lepidoptera damaging cruciferous crops on Long Island, New York. Cornell University Agricultural Experiment Station Memoir 399: 57-99

Thornhill WA. 1983. The distribution and probable importance of linyphiid spiders living on the soil surface of sugar-beet fields. Bulletin of the British Arachnological Society 6: 127-36

US Department of Agriculture. 1958. Soil survey, Ontario and Yates counties, New York. Soil survey, series 1949, No. 5. Soil Conservation Service

Vittum MT, Gibbs GH, Barnard J. 1983. Minimum and maximum temperatures and record periods of warm and cold, wet and dry weather at Geneva, NY. New York State Agricultural Experiment Station Geneva Special Report $\mathbf{4 7}$

Webb SE, Shelton AM. 1988. Laboratory rearing of the imported cabbageworm. New York's Food and Life Sciences Bulletin 122

Weires RW, Chiang HC. 1973. Integrated control prospects of major cabbage insect pests in Minnesota-based on the faunistic, host varietal, and trophic relationships. University of Minnesota Agricultural Experiment Station Technical Bulletin 291

Wheeler AG. 1976. Lygus bugs as facultative predators. pp. 28-35 in DR Scott, LE O'Keefe (Eds.), Lygus Bug-Host Plant Interactions: Proceedings of a workshop held 21 August 1976 in conjunction with the XV International Congress of Entomology, Washington, DC. Moscow: University Press of Idaho

Whitman DW, Nordlund DA. 1994. Plant chemicals and the location of herbivorous arthropods by their natural enemies. pp. 133-59 in TN Ananthakrishnan (Ed.), Functional dynamics of phytophagous insects. Lebanon, New Hampshire: Science Publishers

Wyman JA, Libby JL, Chapman RK. 1976. The role of seed-corn beetles in predation of cabbage maggot immature stages. Environmental Entomology 5: 259-63

Yamamoto M. 1981. Comparison of population dynamics of two pierid butterflies, Pieris rapae crucivora and $P$. napi nesis, living in the same area and feeding on the same plant in Sapporo, northern Japan. Journal of the Faculty of Science Hokkaido University Series VI Zoology 22: 202-49

(Date received: 22 March 2000; date accepted: 14 July 2000) 